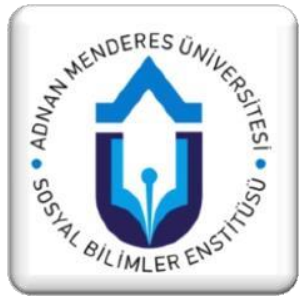

\title{
Engelli Bireylerin Kamu Hizmetlerinden Memnuniyeti: Nazilli İlçesi Örneği ${ }^{1}$
}

\author{
Aslı YENIPAZARLI², Funda ÇONDUR ${ }^{3}$, \\ Necmiye CÖMERTLER ${ }^{4}$
}

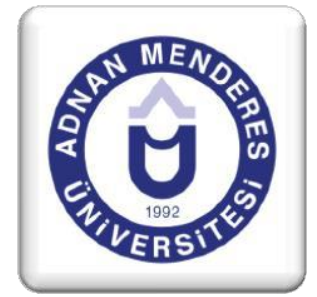

Özet

Dünya Sağlık Örgütü, 2011 tarihli Dünya Engellik Raporu'nda dünyada 18 yaş üzeri nüfusun \%15.6'sının engelli olduğunu belirtmektedir. $\mathrm{OECD}, \mathrm{AB}$ ülkeleri ve Türkiye'de de \%15'inin üzerinde engellilik durumu söz konusudur. Yaşlılık ve kronik hastalıkların giderek artması ile birlikte engelli birey sayısı da artmaktadır. Bu durum ülkelerde engelli bireylerin ihtiyaçlarının ve beklentilerinin de dikkate alındığı politikaları ve uygulamaları gerekli kılmaktadır.

Çalıșmanın amacı Nazilli ilçesindeki engellilerin kamu hizmetlerinden memnuniyetlerinin ortaya konulması, durum ve ihtiyaç analizinin yapılmasıdır. $\mathrm{Bu}$ konuda sosyal farkındalık düzeyinin arttırılması da amaçlanmaktadır.

Çalışmada yerel ölçekte bir alan çalışmasıyla engellilerin kamu hizmetlerinden ve belediyecilik hizmetlerinden memnuniyet durumları belirlenerek memnuniyet düzeyinin engel türüne göre farklılaşıp farklılaşmadığı analiz edilmektedir. Ankete katılan 142 engelli bireylerin yaklaşık olarak yarısını fiziksel engelli bireyler oluşturmaktadır. Engellilerin çoğunluğu kadın, bekar, ilkokul mezunu ve 35-44 yaş aralığındaki bireylerden oluşmaktadır. Engelli bireylerin önemli bir çoğunluğu istihdama katılmamaktadır. Betimleyici istatistikler tüm kamu hizmet kalemlerinde ve genel olarak kamu hizmetlerinden memnuniyetin oldukça yüksek olduğunu göstermektedir. Ancak belediyenin altyapı, sosyal ve kültürel aktiviteler ve sportif aktivitelerinden memnuniyet genel memnuniyet düzeyinin altında kalmaktadır. ANOVA testi sonucu adli ve idari hizmetlerden memnuniyetin engel türüne göre farklılaştı̆̆ını göstermektedir. Engel türüne göre hizmetlerden memnuniyet çoklu karşılaştırmalar analizi fiziksel engelliler ve birden fazla engeli bulunan bireylerin adli ve idari hizmetlerden memnuniyetleri arasında istatistiksel olarak anlamlı bir fark bulunduğunu göstermektedir. Çoklu karşılaştırma sonucu yaygın gelişimsel bozukluk engeli olan bireyler ile birden fazla engeli bulunan bireylerin adli ve idari hizmetlerden memnuniyetleri arasında istatistiksel olarak anlamlı bir fark bulunduğu saptanmıştır.

Anahtar Kelimeler: Engelliler, Kamu Hizmetlerinden Memnuniyet, Yaşam Memnuniyeti

JEL Kodlari: C12, J10, I31

\section{Satisfaction of Disabled People with Public Services: Example of Nazilli Province}

\section{Abstract}

The World Health Organization states in the World Disability Report dated 2011 that $15.6 \%$ of the population over the age of 18 in the world is disabled. OECD, the EU countries and Turkey also have disability above $15 \%$. With the increasing age and chronic diseases, the number of disabled individuals is also increasing. This situation necessitates policies and practices that take into account the needs and expectations of individuals with disabilities while making policies and regulations in countries.

\footnotetext{
${ }^{1} \mathrm{Bu}$ çalışma, 18-20 Haziran 2019 tarihleri arasında düzenlenen, Uluslararası TAEM 2019 Kongresi'nde sunulmuş olan "Engelli Bireylerin Kamu Hizmetlerinden Memnuniyeti: Nazilli İlçesi Örneği”" başlıklı bildiriden yararlanılarak düzenlenmiştir. Çalışmanın anket uygulaması 2020 yılından önce yapıldığından, Etik Kurul Raporu alınmamıştır.

${ }^{2}$ Doç. Dr., ADÜ Nazilli İïBF, İktisat Bölümü öğretim üyesi, (sorumlu yazar) ayenipazarli@adu.edu.tr, Orcid ID: 0000-0002-5078-3037

${ }^{3}$ Doç. Dr., ADÜ Nazilli İ̈BF, İktisat Bölümü öğretim üyesi, fcondur@ adu.edu.tr, Orcid ID:

0000-0003-0570-4333

${ }^{4}$ Prof. Dr., ADÜ Nazilli İIBF, İktisat Bölümü öğretim üyesi, ncomertler@adu.edu.tr, Orcid ID

0000-0002-0370-843X
} 
The main purpose of the study is to reveal the satisfaction of the disabled people in Nazilli district with the public services and to analyze the situation and needs. It is also aimed to increase the level of social awareness on this issue.

In this study, it is analyzed whether the level of satisfaction differs according to the type of disability by determining the satisfaction levels of the disabled from public services and municipal services with a field study on a local scale. Physically disabled individuals constitute close to half of the 142 disabled individuals surveyed. Almost half of the sample consists of physically disabled individuals. The majority of the disabled are women, single, primary school graduates and individuals between the ages of 35-44. A significant majority of disabled individuals do not participate in employment. Descriptive statistics show that satisfaction with all public service items and public services in general is quite high. However, the satisfaction of the municipality with its infrastructure, social, cultural and sports activities is below the general satisfaction level. ANOVA test result shows that satisfaction with judicial and administrative services differs according to the type of disability. The analysis of multiple comparisons of satisfaction with services by type of disability shows that there is a statistically significant difference between physically disabled people and individuals with multiple disabilities in terms of satisfaction with judicial and administrative services. As a result of multiple comparisons, a statistically significant difference was found between individuals with pervasive developmental disabilities and individuals with more than one disability in terms of satisfaction with judicial and administrative services.

Keywords: Disabled, Public Service Satisfaction, Life Satisfaction

Jel Codes: C12, J10, I31 


\section{Giriş}

Toplumda bazı bireyler doğuştan ya da sonradan yaşadıkları hastalık, kaza vb. durumlara bağlı olarak engelli olabilmektirler. Nedenlerine göre zihinsel, görme, işitme ve konuşma, ortopedik ve süreğen engellilik olarak beş farklı engellilik türü bulunmaktadır.

İnsan Hakları Evrensel Beyannamesine göre "Bütün insanlar hür, haysiyet ve haklar bakımından eşit doğarlar". "Her şahsın çalışmaya, işini serbestçe seçmeye, adil ve elverişli çalışma şartlarına ve işsizlikten korunmaya hakkı vardır." (https://www.tbmm.gov.tr/komisyon/insanhaklari/pdf01/203-208.pdf)Dünyada engelli bireyler yasalar karşısında eşit haklara sahip olmakla beraber uygulamada bu haklarını tam ve eşit koşullarda kullanamamaktadırlar. Her bireyin hakkı olan sağlık, eğitim, istihdam, ulaşım ve bilgi edinme gibi temel haklara erişmede engelli bireyler sorunlarla karşılaşmaktadırlar.

Engelli haklarının korunmasına ilişkin olarak engellilerin temel sorun ve ihtiyaçlarının belirlenmesi önem taşımaktadır. Tüm bireylerin eşit koşullarda kamu hizmetlerinden yararlanabilmesi için belirlenen sorun ve ihtiyaçlara dayalı olarak dezavantajlı grup olarak engellilere yönelik projelerin hazırlanması, sorunlarının ortaya çıkarılması ve çözüm önerilerinin oluşturulması gerekmektedir.

Bu çalışmada TÜIKK Yaşam Memnuniyeti Anket Formu dikkate alınarak Aydın ili Nazilli ilçesinde 142 engelli bireye uygulanan bir alan çalışmasıyla engellilerin kamu hizmetlerinden ve belediyecilik hizmetlerinden memnuniyet durumları belirlenerek memnuniyet düzeyinin engel türüne göre farklılaşıp farklılaşmadığı analiz edilmektedir.

\section{Engelli Kavramı}

Engellilik durumunun uluslararası ortak bir tanımı bulunmamaktadır. Dünya Sağlık Örgütü (WHO) engellilik kavramını Birleşmiş Milletler (UN) ve Uluslararası Çalışma Örgütü (ILO)'dan farklı açılardan tanımlamaktadır. Dünya Sağlık Örgütü hastalık sonuçlarına dayanan, sağlık yönüne ağırlık veren tanımlama ve sınıflamalar yaparken, Birleşmiş Milletler ve Uluslararası Çalışma Örgütü ise toplumsal temelli bir yaklaşımla engellilik tanımı yapmaktadır.

Dünya Sağlık Örgütüne göre engellilik noksanlık, özürlülük ve maluliyet kavramlarıyla açıklanmaktadır. Sağlık bakımından noksanlık psikolojik, anatomik veya fiziksel yapı ve fonksiyonlardaki bir noksanlığı veya dengesizliği ifade etmektedir. Özürlülük, sağlık alanında bir noksanlık ya da sakatlık sonucu meydana gelen ve normal sayılabilecek bir insana oranla bir işi yapabilme yeteneğinin kaybedilmesi ve kısıtlanma durumu olarak tanımlanmaktadır. Maluliyet, sağlık alanında bir noksanlık veya sakatlık sonucunda, belirli bir kişide meydana gelen ve o kişinin yaş, cinsiyet, sosyal ve kültürel durumuna göre normal sayılabilecek faaliyette bulunma yeteneğini önleyen ve sınırlayan dezavantajlı bir durumu belirtmektedir (Koca, 2010:4).

Birleşmiş Milletler engellileri, normal bir kişinin ya da sosyal yaşantısında kendi kendisine yapması gereken işleri, bedensel ve ruhsal yeteneklerindeki kalıtımsal ya da sonradan olma herhangi bir noksanlık sonucu yapamayanlar olarak tanımlamıştır.

Uluslararası Çalışma Örgütü'nün 1983 yılında kabul ettiği “Engellilerin Mesleki Rehabilitasyon ve İstihdam Sözleşmesi"nde engelli tanımına yet vermiştir. Bu tanımına göre engelli, uygun bir iş temini, işte kalımı ve işinde ilerlemesi konusundaki beklentileri, kabul edilmiş fiziksel veya zihinsel bir özür sonucu önemli ölçüde azalmış olan bir bireyi ifade etmektedir(ILO). 
Türkiye Cumhuriyeti 5378 Sayılı Özürlüler (Engelliler) Kanunu'na göre; doğuştan veya sonradan herhangi bir nedenle bedensel, zihinsel, ruhsal, duyusal ve sosyal yeteneklerini çeşitli derecelerde kaybetmesi nedeniyle toplumsal yaşama uyum sağlama ve günlük gereksinimlerini karşılama güçlükleri olan ve korunma, bakım, rehabilitasyon, danışmanlık ve destek hizmetlerine ihtiyaç duyan kişi engelli olarak tanımlanmaktadır.

Engellik konusunda yapılan çalışmalar 20. yüzyılın ortalarından itibaren sağlık temelli bakıştan toplumsal yaklaşıma doğru değişmiştir. Bu değişim kamu hizmeti sunanların sorumluluklarını da arttırmıştır. Uluslararası ve ulusal hukuki düzenlemelerle de engelli bireylere ilişkin toplumsal yaklaşım dikkate alınmaktadır (İnce vd., 2016:86).

1980'li yıllardan itibaren özürlülük konusundaki yaklaşımlar farklılaşmış ve özürlülük sınıflandırmasındaki sakatlık ve damgalanmanın sosyal algısını değiştirmek üzere 2001 yılında Dünya Sağlık Örgütü "İşlevsellik, Yeti Yitimi ve Sağlığın Uluslararası Sınıflandırılması" (ICF) sistemini geliştirmiştir. Birleşmiş Milletler de 2001 yılından itibaren bu sınıflandırma sistemini kullanmaktadır. Buna göre özür türleri; görme, işitme, öğrenme ve öğrendiklerini uygulama, zihinsel fonksiyonlar, günlük gereksinmelerini karşılama, iletişim kurma, beden duruşunu değiştirme ve sabit tutma, eşyaları tutma hareket ettirme ve taşıma, yürüme ve hareket etme, öz bakım, temel yaşam aktiviteleri, toplumsal sosyal ve sivil yaşam olarak sınıflandırılmıştır (Bilsin ve Başbakkal, 2014:67).

Engellilik farklı nedenlere dayalı olarak temelde beş türe ayrılmaktadır. Bunlar; zihinsel, görme, işitme ve konuşma, ortopedik ve süreğen engellilik olarak sınıflandırılmaktadır (MEB, 2015). Zihinsel engelli bireyler genel zihinsel işlevlerinde önemli derecede gerilik, uyumsal davranışlarda da yetersizlik ile karşı karşıyadırlar. Görme engelli bireyler görme duyusunun eksikliğini diğer duyu organlarını kullanarak gidermeye çalışmaktadırlar. Dokunarak öğrendikleri için özel araç-gereçlere ihtiyaç duymaktadırlar. İşitme ve konuşma engeli bulunan bireyler merkezi sinir sitemine bağlı olarak vücut koordinasyonunu sağlamada ve denge alanlarında sorun yaşamaktadırlar. İşitme engelli bireylerde dil gelişimi olumsuz etkilenmektedir. Ortopedik engelli, hastalık ve kaza gibi nedenlere bağlı olarak bedensel açıdan özrü olan kişilere denir. Genel olarak kemik, kas ve sinir siteminde meydana gelen bozukluklar nedeni ile toplumsal yaşama uyum sağlayamama ve günlük ihtiyaçlarını sağlamada güçlük yaşayan kişilerdir. Bu kişiler bu nedenlere bağlı olarak koruma, bakım, rehabilitasyon, danışmanlık ve destek hizmetlerine ihtiyaç duymaktadırlar. Süreğen hastalık durumunda ise tıbbi tedavi ve rehabilitasyona rağmen hastalığın, sakatlığın ve yaşanan herhangi bir özrün giderilememesi sonucunda rahatsızlığın süreklilik göstermesidir. $\mathrm{Bu}$ durum kişinin çalışmasına engel oluşturmakta ve sürekli bakım ve tedavi gerektirmektedir (Hacibebekoğlu, 2015: 13-14).

Engelli bireyler fiziksel, sosyal, psikolojik ve ekonomik birçok sorunla karşılaşmaktadır. Yaşadıkları yapılandırılmış çevredeki mimari engeller nedeniyle toplumsal alanlara ulaşmada sorunlar yaşamaktadırlar. Konutların, toplu taşıma araçlarının çoğu engellilere uygun tasarlanmamıştır. Engellilerin karşılaş̧ıkları en temel ekonomik sorunlar işsizlik ve yoksulluktur. Öte yandan demografik özellikleri ve yaşadıkları sosyo ekonomik çevre sorunlarını derinleştirebilmektedir. Cinsiyet, yaş, eğitim durumuna ve kırda ya da kentte yaşamalarına göre engelliğe bağlı yaşanan sorunlar farklılaşmaktadır. Eğitimde alt ve üst yapıdan kaynaklanan engeller ayrı bir sorun teşkil etmektedir. Engelli bireylerin karşılaştıkları tüm bu çevresel, sosyal, kültürel, psikolojik ve ekonomik sorunlar toplumla bütünleşmelerine kaynaşmalarına engel olmaktadır. 


\section{Yaşam Memnuniyeti Kapsamında Kamu Hizmetlerinden Memnuniyet Ve Engelli Bireylerin Kamu Hizmetlerinden Memnuniyeti}

Yaşam memnuniyeti bireyin kendi yaşamını bütünüyle değerlendirmesi sonucunda yaşamından ne derece memnun olduğunu göstermektedir. Yaşam memnuniyeti değerlendirilirken bireyin yaşı, sağlığı, yaşam şekli, kişilik özellikleri etkili olmaktadır. Bunun yanı sıra bireylerin yaşam memnuniyeti düzeylerini sosyal ilişkiler, başarı, doğa ile iç içe olma, beslenme türü, cinsellik, kitap okuma ve müzik dinleme gibi faktörler etkilemektedir (Chow, 2005 ve Dockery, 2003'den aktaran Şeker, 2009:117).

Kamu hizmeti, kamuya yöneltilmiş ve yararlı olarak kabul edilen, kamu kuruluşları tarafindan ya da kamunun gözetimi ve denetimi altında özel sektör tarafından yürütülen faaliyetlerdir (Göküş, 2010:196).

Küreselleşme sürecinde yaşanan bilimsel ve teknolojik gelişmelerle birlikte sosyal ve kültürel alanların artması, kentsel alanlardaki nüfus artışı, sosyo-ekonomik dönüşümler bireylerin kamu hizmetlerine ait talep ve beklentilerini arttırmaktadır.

$\mathrm{Bu}$ süreçte kamu yönetiminde organizasyon ve yönetim anlayışı yerini iş dünyasının toplam kalite ve müşteri memnuniyetini hedefleyen verimlilik yönetimine bırakmıştır. Bireylerin yönetim üzerindeki etkileri ve beklentileri artmış ve memnuniyeti hedefleyen bir anlayış hâkim olmuştur. Kamunun idari hizmetlerinde kalite standartlarını yükseltmeleri gerekli hale gelmiştir (Uçkan, 2003)

Kamu hizmetlerinde kaliteyi belirlemek üzere bazı ölçütler kullanmak gerekmektedir. Genel olarak bu ölçütler; binaların, araçların, iletişim malzemelerinin, personelin görünümü gibi somut özelliklerin yanı sıra hizmeti doğru olarak yerine getirme, isteklilik, yeterlilik, nezaket, dürüstlük, güven, erişilebilirlik, empati gibi hususlardır. Alınan hizmetin kalitesi hizmeti alanların o hizmeti aldıktan sonra hizmetten memnun olup olmadiklarının ifade edilmesi ile değerlendirilmektedir (Çiçek ve Doğan, 2009:203).

Küreselleşme süreci içerisinde sektörlerde ve kurumlarda yapısal değişim ve gelişmeler söz konusu olmuştur. Kamu kurumlarında yaşanan yapısal dönüşümle birlikte yerel yönetimlerde de toplumun yaşam kalitesinin yanı sıra topluma sunulan hizmetlerin ve bu hizmetlerden faydalanan bireylerin memnuniyet düzeylerinin arttırılması önem taşımaktadır (Yurdakul, 2011: 226).

Yerel yönetimler halkın beklentileri, istekleri ve ihtiyaçlarını yerine getirmeye çalışan kurumlardır. Bu kurumlarda amaç sadece hizmetlerin yerine getirilmesi değildir. Önemli olan hizmetler sunulurken halkın memnuniyet durumunun göz önünde bulundurulması ve olası aksaklıkları dikkate alarak alınan düzenleyici tedbirler ve uygulamalarla halkın memnuniyet düzeyinin arttırılmasıdır.

Bireylerin hizmet beklentileri ve beklentilerinin farklılıkları memnuniyet düzeylerini de farklılaştırmaktadır. Bireylerin yaş, eğitim, cinsiyet, gelir, ikamet gibi demografik ve sosyoekonomik özellikleri kamu hizmetlerinden beklentilerini ve memnuniyet düzeylerini etkilemektedir.

Kamu kurum ve yönetimi içerisinde önemli bir yer tutan belediyeler verimli ve kaliteli kamu hizmeti sunmakla yükümlüdürler. Aynı zamanda değişen ve gelişen hizmet politikaları ile yeni kamusal hizmetler üretmek ve sunmak durumundadırlar (Akyıldız, 2012). Öte yandan belediyelerin kamu hizmetlerini sunarlarken karşılaştıkları mali kısıtlar da artmaktadır. Belediyeler kısıtları altında bireylerin taleplerini yenilikçi çözümlerle karşılamaya çalışmalı 
ve sundukları hizmetin kalitesini artırarak bireylerin memnuniyet düzeylerini artırmalı ve bu sayede mutlu kentler için yapılması gerekenlere önem vermelidir.

Belediyelerin engelli bireylere yönelik hizmetleri arasında (Fırat, 2006:91-98);

- Özel merkezler kurmak,

- Bakım ve destek hizmetleri (evde sağlık hizmetleri, günlük hizmetlerin görülmesi, akşam bakım hizmeti),

- Yaşamı kolaylaştırıcı araç desteği,

- Ulaşım hizmetlerinde kolaylik,

- Kentsel düzenlemeler (üst geçitler, bina düzenlemeleri, yeşil alanlar),

- Teknolojik destek sunumları,

- Kültürel etkinlikler,

- Eğitim seminerleri,

- Görme engelliler için okuma ve bilgisayar kullanımı ve üniversiteye hazırlık ve lise destek eğitimi kursları,

- Meslek ve iş edindirme kursları (bedensel engelliler bilgisayar programcılığı eğitimi, engelli kariyer danışmanlığ 1 , servis hizmeti görmek, temizlik ve bulaşıkçılık eğitimi, bilet satı̧ı1 ve takı tasarımı),

- Doğrudan ekonomik yardımlar,

- Engelli spor takımlar1,

- Engelliler dans grubu,

- Ortak gezi vb. programları düzenlemek sayılabilir.

Bireylerin kamu hizmetlerinden memnuniyet düzeylerinin bilinmesi sorunların tespit edilmesi ve çözüm önerilerinin getirilmesi açısından merkezi ve yerel yönetimler için büyük bir öneme sahiptir. Kamu hizmetleri için memnuniyet düzeylerinin ölçülmesinde yaşam memnuniyeti anketleri kullanılmaktadır. Kamu sektörü tarafından verilmekte olan sağlık, güvenlik, eğitim, yarg1 ve ulaştırma hizmetlerinden oluşan memnuniyet endeksi geliştirilmektedir.

Gelişmiş ekonomilerde kamu sektörünün performansı ve hizmet alanların memnuniyet düzeylerini belirlemek üzere hem yerel hem de ulusal düzeyde anketler uygulanmaktadır. Anket sonuçları kamu hizmetlerinin iyileştirilmesi ve reformlar yapılması konusunda kamu kurumlarına yol gösterici olmaktadır. Yapılan anketler kamu hizmetlerinin şekillenmesinde rol oynamaktadır. Aynı zamanda farklı bireylerin kamu hizmetlerini nasıl algıladıklarını ortaya koymaktadır (Çınar ve Köse, 2019:27).

\section{Literatür}

Aslan ve Uluocak (2012), "Belediye hizmetlerinden memnuniyet düzeyleri üzerine bir araştırma: Çanakkale örneği" başlıklı Çanakkale Belediyesinin hizmetlerinden memnuniyetin değerlendirildiği çalışmalarında ankete katılanların çoğunluğunun belediyenin engellilere yönelik faaliyetlerinden memnun olduğunu ortaya koymuştur.

Hacıbebekoğlu, vd. (2015), "Nazilli'de Engellilerin Memnuniyet Analizi” adlı çalışma engelli bireylerin yaşam standartlarını, karşılaştıkları sorunları belirleyerek toplumun 
genelinden, yakın çevrelerinden, kamu kurum ve kuruluşlarından beklentilerini ortaya koymayı ve toplumsal farkındalık yaratmayı amaçlamıştır. Çalışma ilçede söz sahibi olan 20 paydaşla görüşmeler yapılmış ve 100 engelli bireye anket uygulanmıştır. Anket bulgularına göre Nazilli'de engelli bireyler, engellilere yönelik kamu hizmetlerini yeterli bulmadıklarını ifade etmişlerdir. $\mathrm{Bu}$ nedenle çalışmada Nazilli'de yer alan kamu kuruluşlarının engelli bireylere için hizmet kalitelerinin arttırılmasına yönelik bir takım öneriler getirilmiştir. $\mathrm{Bu}$ öneriler arasında engelli bireylere ilişkin istihdamın teşvik edilmesi gerekliliğine yer verilmiştir. İŞKUR ve sivil toplum örgütlerinin bu konuda ortaklaşa çalışmalar yapmaları üzerinde durulmuştur. Engelli bireylerin eğitim düzeylerinin arttırılmasına yönelik eğitim alma haklarındaki erişebilirlik düzeylerinin arttırılması ve girişimcilik ve mesleki eğitim faaliyetlerinin yürütülmesi, rehberlik programlarının arttırılması öngörülmüştür. Sağlık hizmetlerinde, ulaşımda kentin kullanımında engelli bireylere yönelik düzenlemelerin yapılması ve saptanan eksikliklerin giderilmesine yer verilmiştir. Öneriler arasında Nazilli'deki tüm kamu kurumlarının engelsiz tasarlanması, engellilere ilişkin sosyal faaliyetlerin arttırılması, siyasi haklara ulaşabilirlik ve engellilere ilişkin önyargıların ve ayrımcılığın ortadan kaldırılabilmesi için kamu kurumlarının topluma bilinçlendirmede önemli rol oynadıkları belirtilmiştir.

İnce vd. (2016), "Belediye Hizmetleri ve Engelli Vatandaşların Beklentileri Üzerine Amprik Bir Araştırma" adlı çalı̧̧mada Türkiye'de engelli bireylere yönelik hizmetlerin önemli bir kısmını üstlenen belediyelerin sorumlulukları ve çalışmalarını Ankara İlinde 336 kişi ile yapılan görüşmeyle değerlendirmeye çalışmıştır. Görüşmede demografik sosyo-ekonomik bilgiler, engellilik durumu, günlük hayata ilişkin sorunlar ve belediyelerin hizmet ve faaliyetlerine yönelik sorular yöneltilerek durum tespiti yapılmıştır. Yaşanılan sorunlar, belediyelerin sorumluluklarını ne derece yerine getirdikleri ortaya konularak bu sorunların çözümüne ilişkin politika önerileri geliştirilmeye çalışılmıştır. Bu çalışmanın bulgularına göre engelli bireyler temel haklarına ilişkin farkındalıklara sahiplerdir. Erişebilirlik ve ulaşılabilirlik konusundaki hakları belediyelerin sorumlulukları olarak görmektedirler. Ancak yapılan çalışmada engelli bireylerin haklarına dair ve yasaların onları hangi durumlarda koruduğu noktasında bilgi eksiklikleri olduğu da saptanmıştır. Engelli bireylerin hizmetler alanındaki beklentilerinin eğitim hakkı temelinde öne çıktığı görülmektedir.

Şemşit vd. (2016), “Avrupa Birliği Politikaları Perspektifinden Türkiye'de Belediyelerin Sunduğu Engelli Hizmetleri" adlı çalışmalarında 2001 yılından itibaren yerel yönetim yasalarındaki değişikliklerle başta $\mathrm{AB}$ olmak üzere uyum programları ile birlikte reformlar ve iyileştirmelerin yapıldığını ortaya koymaktadır. 2010 yılındaki Anayasa değişikliği ile sosyal devlet anlayışı içerisinde engelli bireylere yönelik yerel yönetimlerin hizmetlerinin düzenlenmesi ve engelli haklarını dikkate alan politikalara ve uygulamalara yer verilmesi gerekliliği üzerinde durulmuştur.

Gül vd. (2017), "Türkiye'de Sosyal Belediyecilik Bağlamında Engellilere Yönelik Hizmetler: Burdur Belediyesi Örneği” adlı çalışmalarında Burdur Belediyesi'nin engelli bireylere yönelik sosyal hizmet ve yardımları incelemiştir. Çalışmada engelli bireylere yönelik hizmetlerin artmasına rağmen yetersiz kaldığı, belediyenin öncelikli hizmetlerinin genel hizmetler olduğu sonucuna varılmıştır.

Şat ve Göver (2017), "Engelliler İçin Belediyelerin Erişilebilirlik Sorumlulukları: Çorum Engel Haritası Projesi" adlı çalışmada kentsel alanda yapılandırılmış çevre düzenlemeleri ve ulaşılabilirlik açısından yerel yönetimlerin sorumlulukları incelenmektedir.Kent merkezinde uygulanan çalışmada proje ekibi kamusal alanlardaki güçlükleri saptamışlardır. Şehrin düzenlenmesindeki aksaklıklar engelli, yaşlı ve güçsüz bireylerin hareket alanlarını sınırlamakta hatta başka yeti kayıplarına da neden olabileceğini ifade etmişlerdir. Fiziksel 
erișilebilirliğin kentlerdeki önemi vurgulanarak bu yönde farkındalık yaratan engelli bireylerin yaşam alanlarını sınırlamalarına neden olmayacak engelsiz kent görünümünün sağlanması üzerinde durulmuştur. Çorum Belediyesi'nin engelsiz erişime yönelik uzman kadrosunu arttırması teknik ve istatistiki bilgileri toplamasının yanı sıra planlayıc1 ve uygulayıcı çalışanların empati çalışmalarına odaklanmaları gerektiği sonucuna varmışlardır.

Sözer vd. (2018), “TR90 Bölgesi Engelli Profili ve İhtiyaç Analizi Raporu” engelli gruplarına göre engelli birey ve ailelerinin karşılaştıkları sorunları tespit etmek ve bu sorunlarının çözümüne yönelik politikaların önerilmesinde paydaşların yapabileceklerinin devlet politikaları ile birlikte ortaya konularak engelli bireylerin işgücüne katılım olanaklarının arttırılması amaçlanmıştır. 138 engelli bireye anket uygulanmıştır.Çalışma bölgesini kapsayan her bir ilde yapılan araştırma sonucunda uygulanan SWOT analizi ile illerin güçlü yanları, zayıf yanları, firsatlar ve tehditler ortaya konulmuştur. Genel olarak engelli birey ve ailelerinin karşılaşmış oldukları sorunlar tespit edilerek engelli bireylere yönelik faaliyet gösteren eğitim merkezlerinin eğitici niteliklerinin arttırılması, fiziksel mekânların engelli bireylerin kullanabilecekleri hale getirilmesi, sağlık, ulaşım, eğitim ve sosyal haklarla ilgili koşulların iyileştirilmesi gerekliliği üzerinde durulmuştur. Kamu ve özel sektör işbirliği içerisinde engelli bireylerin istihdam sorunlarına çözüm getirilmesi gereklikleri yer almıştır.

Ay (2018), "Engellilere Yönelik Yerel Yönetim Hizmetleri: Bursa Büyükşehir Belediyesi Örneği" adlı çalışmanın amacı, yerel yönetimlerin engellilere yönelik sunduğu hizmetlerin değerlendirilmesidir. Bursa Büyükşsehir Belediyesi engellilere yönelik hizmetlerini engelli dernekleri gibi sivil toplum kuruluşları, engelliler meclisi ve ilgili diğer birimlerle birlikte yürütmektedir. Çalışma kapsamında sorunları tespit etmek ve çözümler üretmek üzere 2018 yılında 83 kurum ve kuruluşla toplantılar yapılmıştır. Çalışma sonucunda engellilere yönelik hizmetlerin niceliği ve niteliğinin arttırılması sonucuna varılmıştır.

Babaoğlu (2018), “Türkiye'de Anakentlerde Engellilere Yönelik Hizmetler ve Sorun Alanları" adlı çalışmasında engelli bireylere yönelik hizmetler incelenmiştir. Çalışmada engelli bireylere yönelik hizmetler ile engelli bireylerin beklenti ve taleplerine yönelik değerlendirilmeler yapılarak yaşadıkları sorunlar tespit edilmiştir. Çalışmada, engelli bireylere yönelik hizmetlerin onların yasal hakları olduğundan hareketle düzenlenmesi gerekliliği vurgulanmıştır. Engelli bireylerin haklarını kullanım noktalarında sivil toplum kuruluşlarının da önemli rol oynadığı vurgulanmıştır. Ayrıca kent konseylerinde yer alan engelli meclislerine işlerlik kazandırılması çözüm önerilerinin geliştirilmesinde önemli olduğu belirtilmiştir.

Genel olarak yapılan çalışmaların sonuçları değerlendirildiğinde engelli bireylere yönelik hizmetlerin sağlanmasında yetersizliklerin olduğu görülmektedir.

\section{Nazilli'de Yaşayan Engelli Bireylerin Kamu Hizmetlerinden Memnuniyeti}

TÜiK "Yaşam Memnuniyeti Anketi”nden yararlanarak geliştirilen 27 soruluk ankette engellilerin demografik özellikleri ve kamu ve belediyecilik hizmetlerinden memnuniyetlerini ölçmeye yönelik açık ve kapalı uçlu sorular bulunmaktadır. Çalışmanın evrenini Nazilli ilçesinde yaşayan tüm engelli bireyler oluşturmaktadır. Örneklem seçiminde engelli bireylere ulaşma zorluğu nedeniyle kasti örneklem yöntemi kullanılmıştır. Nazilli ilçesinde yaşayan, NAZENDER ve Nazilli Bedensel Engelliler Derneği üyesi 142 engelli birey çalışmanın örneklemi olarak seçilmiştir. Anket formları engelli bireyin kendisi ya da bir yakını tarafından doldurulmuştur. Veri analizinde SPSS programı kullanılmıştır. Çalışmada betimleyici istatistikler sunulduktan sonra farklılıkları ortaya koymak üzere Temel Bileşenler Analizi, Faktör Ayrıştırması ve ANOVA Analizi yapılmıştır. 


\subsection{Analiz Sonuçları Ve Bulguların Değerlendirilmesi}

Anketlerin uygulandığı 142 engelli bireyin engellilik durumu ve demografik özelliklerine ilişkin bilgiler Tablo 1 ve Tablo 2'de özetlenmiştir.

Tablo 1: Engellik Durumu

\begin{tabular}{|l|l|l|}
\hline \multicolumn{2}{|l|}{ Değişken } & Yüzde \\
\hline Engel Durumu & Fiziksel & 47,9 \\
\cline { 2 - 3 } & Görme & 5,6 \\
\cline { 2 - 3 } & İşitme & 5,6 \\
\cline { 2 - 3 } & Özgül Öğrenme Güçlüğü & 2,1 \\
\cline { 2 - 3 } & Spastik Engel & 7,0 \\
\cline { 2 - 3 } & Dikkat Eksikliği Hiperaktivite Bozukluğu & 5,6 \\
\cline { 2 - 3 } & Yaygın Gelişimsel Bozukluk & 2,8 \\
\cline { 2 - 3 } & Dil ve Konuşma Bozukluğu & 4,9 \\
\cline { 2 - 3 } & Birden Fazla Engellilik Durumu & 16,2 \\
\cline { 2 - 3 } & Zihinsel & 2,1 \\
\hline
\end{tabular}

Tablo 1'den görüleceği üzere örneklemin yarısına yakın bir kısmını $(\% 47,9)$ fiziksel engelli bireyler, \%16,2'sini birden fazla engeli olan bireyler, \%7'sini spastik engelli bireyler oluşturmaktadır.

Tablo 2: Demografik Özellikler

\begin{tabular}{|c|c|c|c|c|c|}
\hline \multicolumn{2}{|l|}{ Değişken } & \multirow{2}{*}{$\begin{array}{l}\text { Yüzde } \\
57,0\end{array}$} & \multicolumn{2}{|l|}{ Değişken } & \multirow{2}{*}{$\begin{array}{l}\text { Yüzde } \\
45,8\end{array}$} \\
\hline Cinsiyet & Kadın & & Medeni & Evli & \\
\hline & Erkek & 43,0 & Durum & Bekar & 54,2 \\
\hline \multirow[t]{7}{*}{ Yaş } & $0-15$ & 2,8 & \multirow{7}{*}{$\begin{array}{l}\text { Öğrenim } \\
\text { Durumu }\end{array}$} & $\begin{array}{l}\text { Okuryazar } \\
\text { Olmayan }\end{array}$ & 29,6 \\
\hline & $16-24$ & 12,0 & & Okuryazar & 4,2 \\
\hline & $25-34$ & 20,4 & & İlkokul & 30,3 \\
\hline & $35-44$ & 31,7 & & $\begin{array}{ll}\text { Ortaokul } \\
\text { İlköğretim }\end{array}$ & 12,7 \\
\hline & $45-54$ & 19,7 & & Genel Lise & 16,7 \\
\hline & $55-64$ & 7,0 & & $\begin{array}{l}\text { Meslek veya } \\
\text { Teknik Lise }\end{array}$ & 0,0 \\
\hline & 65 ve üzeri & 6,3 & & $\begin{array}{l}\text { Yüksekokul } \\
\text { Fakülte ve } \\
\text { Üzeri }\end{array}$ & 7,0 \\
\hline \multirow{5}{*}{$\begin{array}{l}\text { Çalışma } \\
\text { Durumu }\end{array}$} & Çalışyyor & 11,3 & \multirow{7}{*}{$\begin{array}{l}\text { Yıllık } \\
\text { Ortalama } \\
\text { Gelir (TL) }\end{array}$} & 0 & 50,0 \\
\hline & Çalışmıyor & 88,7 & & $1-5000$ & 5,6 \\
\hline & & & & $5001-10000$ & 2,1 \\
\hline & & & & $10001-15000$ & 21,8 \\
\hline & & & & $15001-20000$ & 8,5 \\
\hline \multirow{9}{*}{$\begin{array}{l}\text { Çalışmama } \\
\text { Nedeni }\end{array}$} & İș bulamama & 19,0 & & $20001-30000$ & 9,2 \\
\hline & Eğitim & 3,5 & & 30001 ve üzeri & 2,8 \\
\hline & Çocuk yaşlı hasta bakımıyla uğraşmak & 12,7 & \multirow[t]{7}{*}{ Meslek } & Yok & 73,2 \\
\hline & Emekli & 11,3 & & Ev Hanımı & 14,8 \\
\hline & Engelli & 31,7 & & Çiftçi & 2,1 \\
\hline & Yaşl1lık & 3,5 & & Mühendis & 0,7 \\
\hline & Hastalık & 2,8 & & Emekli & 5,6 \\
\hline & İrad sahibi & 0,0 & & İşçi & 2,1 \\
\hline & Kişisel tercih & 5,6 & & Sekreter & 0,7 \\
\hline
\end{tabular}




\begin{tabular}{|l|l|l|l|l|l|l|}
\hline & Ailevi & 1,4 & & & Memur & 0,7 \\
\hline
\end{tabular}

Örneklemin çoğunluğu kadın (\%57), bekar (\%54,2), ilkokul mezunu (\%30,3) ve 35-44 yaş aralı̆̆ındaki bireylerden $(\% 31,7)$ oluşmaktadır. Engelli bireylerin \%88,7 çalışmamakta, istihdama katılmamaktadır. Çalışmama nedenlerinin başında engelli olmaları $(\% 31,7)$ gelirken iş bulamama (\%19) ikinci önemli neden olarak belirtilmektedir. Engelli bireylerin yaklaşık \%88'inin herhangi bir mesleği yoktur. Örneklemin yarısını oluşturan engellilerin hiçbir gelirleri bulunmamaktadır.

Tablo 3: Kamu Hizmetlerinden Memnuniyet (\%)

\begin{tabular}{|l|l|l|l|l|l|l|}
\hline & $\begin{array}{l}\text { çok } \\
\text { memnun }\end{array}$ & memnun & orta & $\begin{array}{l}\text { memnun } \\
\text { değil }\end{array}$ & $\begin{array}{l}\text { hiç memnun } \\
\text { değil }\end{array}$ & $\begin{array}{l}\text { fikri } \\
\text { yok }\end{array}$ \\
\hline Sağlık hizmetlerinden & 6,3 & 40,1 & 24,6 & 17,6 & 7,7 & 3,5 \\
\hline Asayiş hizmetlerinden & 10,6 & 36,6 & 23,2 & 9,9 & 3,5 & 16,2 \\
\hline Adli hizmetlerden & 7,0 & 48,7 & 15,5 & 10,6 & 4,9 & 18,3 \\
\hline Eğitim hizmetlerinden & 5,6 & 41,5 & 17,6 & 12,0 & 7,0 & 16,2 \\
\hline $\begin{array}{l}\text { Sosyal Güvenlik Kurumu } \\
\text { hizmetlerinden }\end{array}$ & 8,5 & 41,5 & 24,6 & 12,0 & 7,0 & 6,3 \\
\hline Ulaştırma hizmetlerinden & 12,0 & 31,7 & 19,7 & 16,2 & 4,2 & 16,2 \\
\hline $\begin{array}{l}\text { Elektronik krtamda } \\
\text { sunulan } \\
\text { hizmetlerinden }\end{array}$ & 9,2 & 27,5 & 19,7 & 11,3 & 5,6 & 26,8 \\
\hline $\begin{array}{l}\text { Genel olarak kamu } \\
\text { hizmetlerinden }\end{array}$ & 7,7 & 41,5 & 29,6 & 12,7 & 2,8 & 5,6 \\
\hline
\end{tabular}

Betimleyici istatistikler tüm kamu hizmet kalemlerinde ve genel olarak kamu hizmetlerinden memnuniyetin oldukça yüksek olduğunu göstermektedir. Ankete katılan 142 engelli bireyin $\% 7,7$ 'si genel olarak kamu hizmetlerinden çok memnun ve \% 41,5'i memnunken memnun olmayanlar \%12,7 ve hiç memnun olmayanlar \%2,8'dir. Memnuniyetin en fazla olduğu hizmet adli hizmetler $(\% 55,7)$ olarak belirtilmektedir.

Tablo 4: Belediyelerin Hizmetlerinden Memnuniyet (\%)

\begin{tabular}{|l|l|l|l|l|l|l|}
\hline & $\begin{array}{l}\text { cok } \\
\text { memnun }\end{array}$ & memnun & orta & $\begin{array}{l}\text { memnun } \\
\text { değil }\end{array}$ & $\begin{array}{l}\text { hiç } \\
\text { memnun } \\
\text { değil }\end{array}$ & $\begin{array}{l}\text { fikri } \\
\text { yok }\end{array}$ \\
\hline $\begin{array}{l}\text { Belediyenin engellilere yönelik } \\
\text { hizmetlerinden }\end{array}$ & 10,6 & 41,5 & 19,7 & 12,0 & 5,6 & 10,6 \\
\hline $\begin{array}{l}\text { Belediyenin engellilere yönelik } \\
\text { alt yapı hizmetlerinden }\end{array}$ & 8,5 & 33,8 & 22,5 & 16,2 & 7,0 & 12,0 \\
\hline $\begin{array}{l}\text { Belediyenin engellilere yönelik } \\
\text { sosyal ve } \\
\text { aktivitelerinden }\end{array}$ & 8,5 & 35,2 & 24,6 & 10,6 & 4,9 & 16,2 \\
\hline $\begin{array}{l}\text { Belediyenin engellilere yönelik } \\
\text { sportif aktivitelerinden }\end{array}$ & 7,7 & 30,3 & 19,0 & 14,8 & 7,0 & 21,1 \\
\hline $\begin{array}{l}\text { Genel olarak Belediyenin } \\
\text { hizmetlerinden }\end{array}$ & 9,9 & 47,9 & 24,6 & 7,7 & 4,9 & 4,9 \\
\hline
\end{tabular}

Ankete katılan 142 engelli bireylerin yaklaşık olarak yarısı genel olarak belediye hizmetlerinden (\%57,8’i) ve yine belediyenin engellilere yönelik hizmetlerinden (\%52,1’i) 
çok memnun veya memnun olduğunu belirtmiştir. Ancak belediyenin altyapı, sosyal ve kültürel aktiviteler ve sportif aktivitelerinden memnuniyet genel memnuniyet düzeyinin altında kalmaktadır. Belediyenin engellilere yönelik alt yapı hizmetlerinden engellilerin \% 42,3'ü, sosyal ve kültürel aktivitelerden \% 43,7'si ve sportif aktivitelerinden \%38'i çok memnun veya memnundur. Belediye hizmetlerinden memnun olmayan ya da hiç memnun olmayanları oranı en fazla alt yap1 hizmetlerinde \% 23,2 en az genel belediyecilik hizmetlerinde \%12,6 olarak ortaya çıkmaktadır.

Tablo 5: Güvenilirlik İstatistiği

\begin{tabular}{|l|l|}
\hline Cronbach's Alpha & N of Items \\
\hline, 894 & 15 \\
\hline
\end{tabular}

Tablo 5'de yer alan güvenilirlik istatistiği değerinin $\alpha>0.80$ olması anketin yüksek güvenilirliğe sahip olduğunu göstermektedir.

\subsection{Faktör Analizi}

Faktör analizi aralarında ilişki olduğu düşünülen çok sayıdaki değişken arasındaki ilişkilerin anlaşılması ve yorumlanmasının kolaylaştırılması amacıyla değişkenlerin daha az sayıdaki temel boyuta indirgenmesi ve özetlenmesidir. Faktör analizinde temel mantık, karmaşık bir olgunun daha az sayıda faktörler (temel değişkenler) yardımıyla açıklanabileceği düşüncesidir. Etkin bir faktör analizinin toplam veri setini en iyi temsil edebilen ancak mümkün olduğunca az sayıda faktörden oluşması istenir (Coşkun, Altunışık ve Yıldırım, 2017: 270).

Bu çalışmada toplam 13 maddeden oluşan ölçeğe faktör analizi yapılmıştır. Verilerin faktör analizine uygunluğunu test etmek için Kaiser-Meyer-Olkin Örneklem Yeterlilik Testi (KMO) ve Bartlett Testi yapılmıştır. KMO değerinin 1'e yakın olması durumunda veri setinin faktör analizine uygun olduğu kabul edilmektedir. Veri matrisinin birim matris olup olmadığına, değişkenler arasındaki korelasyonun yeterli olup olmadığına karar vermek için Bartlett testi sonucunun 0,5'den küçük olması istenir.

Tablo 6:KMO ve Bartlett Test Sonuçları

\begin{tabular}{|l|l|l|}
\hline KMO & Ki-Kare Değeri & 0,843 \\
\cline { 2 - 3 } Bartlett Testi & S.d. & 1069,347 \\
\cline { 2 - 3 } & $\mathbf{p}$ & 91 \\
\hline
\end{tabular}

Tablo 6'daki analiz sonuçlarından görüldüğü üzere KMO testi sonucu \%84,3 bulunmuştur. $\mathrm{KMO}=0,843>0,500$ ve bire yakın olduğundan anket faktör analizi yapmaya uygundur. Bartlett testi sonucunda $\mathrm{p}=0.000<0.500$ olduğundan değişkenler arasında yüksek korelasyon vardır. Yani veri seti faktör analizi yapmaya uygundur. Veri setinin faktör analizine uygunluğu test edildikten sonra faktör yapısını incelemek için Temel Bileşenler Analizi yapılmıştır.

Temel Bileşenler Analizi, bir veri kümesindeki değişkenlerin sayısının azaltılması anlamına gelmektedir. Veriler satır ve sütun formatında ise girdi değişkenleri hedef değişkeni tahmin etmek için bir modele girdi olarak kullanılan değişkenlerdir. Girdi değişkenlerinin çok 
olması daha güvenilir sonuçların elde edilmesini sağlamaktadır (Gürsakal ve Çelik, 2020:183).

Varimax Rotasyon yöntemi kullanılarak yapılan analizler sonucunda tüm maddelerin faktör yüklerinin analize uygun olduğu bulunmuştur. $\mathrm{Bu}$ sebeple tüm maddelere faktör analizi uygulanmıştır. Faktör analizi sonucunda elde edilen sonuçlar Tablo 7'de verilmiştir.

Tablo 7: Açıklayıcı Faktör Analizi Sonuçları

\begin{tabular}{|c|c|c|c|c|c|c|c|c|c|}
\hline \multirow[b]{2}{*}{ Faktör } & \multicolumn{3}{|l|}{ Özdeğer } & \multicolumn{3}{|c|}{ Döndürülmemiş çözüm } & \multicolumn{3}{|c|}{ Döndürülmüş çözüm } \\
\hline & $\begin{array}{l}\text { Toplam } \\
\text { özdeğer }\end{array}$ & $\begin{array}{l}\text { Varyansın } \\
\text { yüzdesi }\end{array}$ & $\begin{array}{l}\text { Kümülatif } \\
\%\end{array}$ & $\begin{array}{l}\text { Toplam } \\
\text { özdeğer }\end{array}$ & $\begin{array}{l}\text { Varyansin } \\
\text { yüzdesi }\end{array}$ & $\begin{array}{l}\text { Kümülatif } \\
\%\end{array}$ & \begin{tabular}{|l|} 
Toplam \\
özdeğer
\end{tabular} & $\begin{array}{l}\text { Varyansin } \\
\text { yüzdesi }\end{array}$ & $\begin{array}{l}\text { Kümülatif } \\
\%\end{array}$ \\
\hline $\begin{array}{l}1 \\
2 \\
3 \\
4 \\
5 \\
6 \\
7 \\
8 \\
9 \\
10 \\
11 \\
12 \\
13 \\
14\end{array}$ & $\begin{array}{l}6,128 \\
1,844 \\
1,341 \\
, 765 \\
, 662 \\
, 612 \\
, 512 \\
, 446 \\
401 \\
, 374 \\
, 297 \\
, 277 \\
, 197 \\
144\end{array}$ & \begin{tabular}{|l}
43,770 \\
13,175 \\
9,581 \\
5,467 \\
4,731 \\
4,370 \\
3,660 \\
3,186 \\
2,862 \\
2,668 \\
2,124 \\
1,976 \\
1,404 \\
1,027
\end{tabular} & \begin{tabular}{|l}
43,770 \\
56,945 \\
66,526 \\
71,993 \\
76,724 \\
81,093 \\
84,754 \\
87,940 \\
90,801 \\
93,469 \\
95,593 \\
97,569 \\
98,973 \\
100,000
\end{tabular} & $\begin{array}{l}6,128 \\
1,844 \\
1,341\end{array}$ & $\begin{array}{l}43,770 \\
13,175 \\
9,581\end{array}$ & $\begin{array}{l}43,770 \\
56,945 \\
66,526\end{array}$ & $\begin{array}{l}3,472 \\
3,130 \\
2,711\end{array}$ & $\begin{array}{l}24,801 \\
22,361 \\
19,364\end{array}$ & $\begin{array}{l}24,801 \\
47,162 \\
66,526\end{array}$ \\
\hline
\end{tabular}

Çıkarım Yöntemi: Temel Bileşenler Analizi

Tablo 7'den görüleceği üzere özdeğerin birden büyük olduğu üç faktör bulunmaktadır. Bu üç faktör toplam varyansın \%66,526'sını açıklamaktadır. Döndürülmemiş çözümde 1. Faktör toplam varyansın $\% 43,7$ 'sini ve açılanan varyansın \%65'ini açıklamaktadır. Döndürülmüş çözümde 1. FAKTÖR'ün etkisi azalmakta ve toplam varyansın $\% 24,8$ ve açıklanan varyansın \%37,28'ini açıklayabilmektedir. Döndürülmüş çözümde 1. Faktör ve 2. Faktörün açıklama gücünün çok yakın olduğu görülmektedir.

Büyüköztürk'e (2002) göre maddelerin ait olduğu faktör yük değerleri için 0.45 'ten büyük değerlerin madde seçimi için iyi bir ölçüt olduğunu kabul edilmektedir.

Tablo 8: Faktör Yük Değeri Yorumu

\begin{tabular}{|l|l|}
\hline Faktör Yükü Değeri & Yorum \\
\hline 0.71 ve üzeri & Mükemmel \\
\hline $0.63-0.70$ & Çok İyi \\
\hline $0.55-0.62$ & İyi \\
\hline $0.45-0.54$ & Normal \\
\hline $0.32-0.44$ & Kötü \\
\hline
\end{tabular}

Kaynak: (Comrey ve Lee, 1992).

Faktör analizi sonuçları dikkate alındığında, rotasyon (döndürme) sonucunda maddeler toplam 3 faktör altında toplanmıştır. FAKTÖR 1: Belediye hizmetlerinden memnuniyet, 
FAKTÖR 2: Adli ve İdari Hizmetlerden Memnuniyet ve FAKTÖR 3: Temel Kamu Hizmetlerinden Memnuniyet olarak isimlendirilmiştir. Maddelere ilişkin faktör yükleri ise 0.640 ile 0.846 aralığında değişim göstermektedir. Tablo 8'deki ölçütler dikkate alındığında 4 madde için 0.63-0.70 arasında "çok iyi" ve 9 madde içinde 0.71 ve üzerinde "mükemmel" olarak yorumlanabilir (Comrey ve Lee, 1992). Faktör analizi ile elde edilen üç faktörün altında yer alan guruplar şöyledir:

FAKTÖR 1: Belediye hizmetlerinden memnuniyet

Belediye hizmetlerinden memnuniyeti ölçen maddeler; belediye hizmetlerinden genel memnuniyet, belediyenin engellilere yönelik hizmetlerinden memnuniyet, belediyenin engellilere yönelik altyapı hizmetlerinden memnuniyet, belediyenin engellilere yönelik sosyal kültürel hizmetlerinden memnuniyet, belediyenin sportif aktivitelerinden memnuniyettir.

FAKTÖR 2: Adli ve İdari Hizmetlerden Memnuniyet

Adli ve idari hizmetlerden memnuniyeti ölçen sorular asayiş hizmetlerinden memnuniyet, adli hizmetlerden memnuniyet, ulaştırma hizmetlerinden memnuniyet, elektronik kamu hizmetlerinden memnuniyettir.

FAKTÖR 3: Temel Kamu Hizmetlerinden Memnuniyet

Temel kamu hizmetlerinden memnuniyeti ölçen sorular yaşamdan bir bütün olarak memnuniyet durumu, sağlık hizmetlerinden memnuniyet, genel olarak kamu hizmetlerinden memnuniyet, SGK hizmetlerinden memnuniyet olmaktadır.

Tablo 9: Döndürülmüş Bileşke Matris

\begin{tabular}{|c|c|c|c|}
\hline & \multicolumn{3}{|c|}{ Faktörler } \\
\hline & $\begin{array}{l}\text { Faktör } \\
1\end{array}$ & $\begin{array}{l}\text { Faktör } \\
2\end{array}$ & Faktör 3 \\
\hline Belediye Hizmetlerinden Genel Memnuniyet & 662 & & \\
\hline Belediyelerin Engellilere Yönelik Memnuniyet & ,846 & & \\
\hline Belediyelerin Engellilere Yönelik Altyapı Hzm. Memnuniyet & ,801 & & \\
\hline 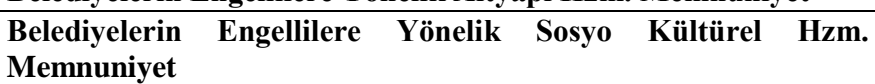 & ,795 & & \\
\hline 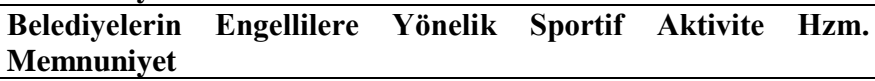 & ,777 & & \\
\hline Asayiș Hizmetlerinden Memnuniyet & & ,826 & \\
\hline Adli Hizmetlerden Memnuniyet & & ,836 & \\
\hline Ulaştırma Hizmetlerinden Memnuniyet & & 666 & \\
\hline Elektronik Kamu Hizmetlerinden Memnuniyet & & ,777 & \\
\hline Bir Bütün Olarak Yaşam Mutluluğu & & & 640 \\
\hline Sağlık Hizmetlerinden Memnuniyet & & & ,730 \\
\hline SGK Hizmetlerinden Memnuniyet & & & ,777 \\
\hline Genel Olarak Kamu Hizmetlerinden Memnuniyet & & & 675 \\
\hline
\end{tabular}

Çıkarım Yöntemi: Temel Bileşenler Analizi.

Döndürme Metodu: Varimax(Kaise Normalleştirme

Döndürülmüş Faktör Matrisi (Rotated Component Matrix) kullanılarak yapılan analizin sonucunda elde edilen üç faktörün hangi maddelerden oluştuğu ve yükleri Tablo 9'da verilmiştir. Tablodaki sonuçlara ulaşmak için 0.50 'den küçük değerler ihmal edilmiştir.

\subsection{ANOVA Analizi}


Engelli bireylerin engel türüne göre üç FAKTÖR arasında istatistiksel olarak anlamlı bir farklılığın olup olmadığını belirlemek üzere ANOVA analizi yapılmıştır.

Tablo 10: Engel Türüne Göre Hizmetlerden Memnuniyet ANOVA Analizi

\begin{tabular}{|c|c|c|c|c|c|c|}
\hline & & $\begin{array}{l}\text { Kareler } \\
\text { Toplamı }\end{array}$ & $\begin{array}{l}\text { Serbestlik } \\
\text { derecesi }\end{array}$ & \begin{tabular}{|l} 
Kareler \\
Ortalamas1
\end{tabular} & $\mathrm{F}$ & \begin{tabular}{|l|} 
Anlamll1ık \\
Düzeyi
\end{tabular} \\
\hline $\begin{array}{l}\text { 1. FAKTÖR için } \\
\text { regresyon analizi }\end{array}$ & $\begin{array}{l}\text { Gruplar aras1 } \\
\text { Grup içi } \\
\text { Toplam }\end{array}$ & $\begin{array}{l}7,900 \\
133,100 \\
141,000 \\
\end{array}$ & $\begin{array}{l}9 \\
132 \\
141 \\
\end{array}$ & $\begin{array}{l}, 878 \\
1,008\end{array}$ & 871 &, 553 \\
\hline $\begin{array}{l}\text { 2. FAKTÖR için } \\
\text { regresyon analizi }\end{array}$ & $\begin{array}{l}\text { Gruplar aras1 } \\
\text { Grup içi } \\
\text { Toplam }\end{array}$ & $\begin{array}{l}31,570 \\
109,430 \\
141,000\end{array}$ & $\begin{array}{l}9 \\
132 \\
141 \\
\end{array}$ & $\begin{array}{l}3,508 \\
829\end{array}$ & 4,231 &, 000 \\
\hline $\begin{array}{l}\text { 3. FAKTÖR için } \\
\text { regresyon analizi }\end{array}$ & $\begin{array}{l}\text { Gruplar aras1 } \\
\text { Grup içi } \\
\text { Toplam }\end{array}$ & $\begin{array}{l}5,676 \\
135,324 \\
141,000\end{array}$ & $\begin{array}{l}9 \\
132 \\
141\end{array}$ & $\begin{array}{l}, 631 \\
1,025\end{array}$ & 615 &, 782 \\
\hline
\end{tabular}

ANOVA analizi sonuçlarına göre 2. FAKTÖR için $p=0,00<0.05$ olduğundan gruplar arasında istatistiksel olarak anlamlı bir farkın olduğu söylenebilir. 1. FAKTÖR ve 3.FAKTÖR için $p>0,05$ olduğu için gruplar arasında istatistiksel olarak anlamlı bir fark yoktur.

ANOVA analizi gruplar arasında istatistiksel olarak anlamlı bir fark olup olmadığını gösterse de farklılıkların hangi gruplar arasında olduğuna dair bilgi vermez. Gruplar arasındaki farklı1ığın hangi gruptan kaynaklandığını belirlemek tek yönlü ANOVA testinde yer alan Scheffe, LSD, Bonferonni,Tukeyvb testlerden birini uygulamak gerekir (Coşkun, Altunışık ve Yildırım, 2017: 270).

ANOVA testi sonucu adli ve idari hizmetlerden memnuniyetin engel türüne göre farklılaştığını göstermekte ancak bu farklılaşmanın hangi engel grubundan kaynaklandığına dair bilgi vermemektedir. Bu nedenle Tukey testi ile gruplar arası çoklu karşılaştırmalar yapılmıştır.

Engel türüne göre hizmetlerden memnuniyet çoklu karşılaştırmalar analizi fiziksel engelliler ve birden fazla engeli bulunan bireylerin adli ve idari hizmetlerden memnuniyetleri arasinda istatistiksel olarak anlamlı bir fark bulunduğunu göstermektedir. Çoklu karşılaştırma sonucu yaygın gelişimsel bozukluk engeli olan bireyler ile birden fazla engeli bulunan bireylerin adli ve idari hizmetlerden memnuniyetleri arasında istatistiksel olarak anlamlı bir fark bulunduğu saptanmiştır.

\section{Sonuç}

Engelli bireyler, toplumun dezavantajlı grupları arasında yer almaktadırlar. Dezavatajlı gruplarda bulunan insanların da her bir vatandaş gibi standart yaşam koşullarında, toplumla iç içe ve yüksek düzeyde yaşam memnuniyeti ile yaşama hakları vardır. Bu yönüyle engelli bireyler, gerek istihdam, gerekse sosyal hizmetlerden memnuniyet düzeyleri konusunda birçok araştırmada yer almıştır. Engelli araştırmaları hızlı gelişen sanayi ve teknoloji düzeylerinde, artan sosyal hareketlilikle beraber, engelli bireylerin her bir vatandaşla aynı koşul ve standartlarda aynı yaşam memnuniyetine sahip olmadıklarını ortaya koymuştur. 
Sosyolojik yönüyle de toplumda dezavantajlı grupların "normal vatandaş" olarak adlandırılan diğer insanlardan dışlanmış, düşük yaşam memnuniyetine sahip olmaları toplumsal gelişmişlik düzeyinin de bir yansımasıdır. Eşit koşul ve standartlar gerek uyum düzeyini gerekse psikolojik boyutta hayata bakışı etkilemektedir. Bu yönüyle engelli araştırmaları birçok disiplin çerçevesinde önem taşımaktadır.

Yaşam memnuniyeti bir yönüyle bireylerin kamu hizmetlerinden memnuniyeti ile ölçülebilmektedir. Yerel yönetimlerin (belediyelerin) sundukları hizmetler de kamu hizmetleri çerçevesinde yaşam memnuniyetinin bir ölçütü olarak kabul edilebilmektedir. Engelliler için temel hizmetlere erişim, toplumsal ve kültürel bütünleşme gibi unsurların yetersizliği bir diğer engellilik durumudur.

Betimleyici istatistiklerden Nazilli'deki engelli bireylerin tüm kamu hizmet kalemlerinden ve genel olarak kamu hizmetlerinden memnuniyetinin oldukça yüksek olduğu anlaşılmaktadır. Memnuniyetin en fazla olduğu kamu hizmeti adli hizmetlerdir. Benzer bir sonuç belediye hizmetleri içinde söylenebilir. Ankete katılan 142 engelli bireyin yaklaşık olarak yarısı genel olarak belediye hizmetlerinden ve belediyenin engellilere yönelik hizmetlerinden memnun olduğunu belirtmiştir. Ancak belediyenin altyapı, sosyal ve kültürel aktiviteler ve sportif aktivitelerinden memnuniyet genel memnuniyet düzeyinin altında kalmaktadır. Engelsiz şehirleşmeye uygun sosyal, kültürel ve sportif yaşam alanlarının oluşturulması engelli bireylerin karşılaştıkları sorunları en aza indirerek yaşamlarını daha kolay hale getirerek yaşam kalitelerini yükseltecektir.

Engelsiz şehirler yaklaşımından hareketle oluşturulan yaşam alanları engelli bireylerin karşılaştıkları sorunları en aza indirerek yaşamlarını kolaylaştıracaktır. Yerel yönetimler şehrin planlanmasında, tüm bireylerin hayatını kolaylaştıracak uygulamalara yer vermelidirler. Bu çalışma bağlamında değerlendirilecek olursa, yerel yönetimler faaliyet ve proje bazında engelli bireylerin sosyal içerme çerçevesinde topluma kazandırılmaları ile ilgili çalışmalarını artırmalıdırlar. Engelli bireylere dönük proje ve faaliyetlerin geliştirilmesi engelli bireyin kendisine ekonomik, sosyal ve fiziksel birçok olumlu katkıda bulunacaktır. Yanı sıra toplumsal olarak engellilere bakış açısını değiştirmek, geliştirmek gelişmişlik derecesinin en önemli belirtilerini temsil edecektir. Unutmamak gerekir ki "herkes bir engelli adayıdır", bu da kişi ve kurumların gerekli empatiyle konuya yaklaşmaları için yeterlidir. 


\section{Kaynaklar}

AKYILDIZ, F. (2012). Belediye Hizmetleri ve Vatandaş Memnuniyeti: Uşak belediyesi Örneği. Journal of Yaşar University. 26(7):4415-4436.

ASLAN, C. ve ULUOCAK, Ş. (2012). Belediye Hizmetlerinden Memnuniyet Düzeyleri Üzerine Bir Araştırma: Çanakkale Örneği. Uluslararası İnsan Bilimleri Dergisi. 9(1): 175201.

AY, H. (2018). Engellilere Yönelik Yerel Yönetim Hizmetleri: Bursa Büyükşehir Belediyesi Örneği. Uşak Üniversitesi Sosyal Bilimler Enstitüsü. Basılmamış Yüksek Lisans Tezi.

BABAOĞLU, C. (2018). Türkiye'de Anakentlerde Engellilere Yönelik Hizmetler ve Sorun Alanları. TESAM Akademi Dergisi. Yerel Yönetimler Özel Sayıs1. 79-110.

BİLSİ, E. ve BAŞBAKKAL, Z. (2014). Dünyada ve Türkiye'de Engelli Çocuklar, Ege Üniversitesi Hemşirelik Fakültesi Dergisi. 30(2): 65-78.

BÜYÜKÖZTÜRK, Ş. (2002). Sosyal Bilimler İçin Veri Analizi El Kitabı. 2. Baskı. PegemYayıncılık.Ankara.

COMREY, A. L., and LEE, H. B. (1992). A First Course in Factor Analysis. (2th Edition), New Jersey: Lawrence Erlbaum Associates, Publishers, Hillsdale.

COŞKUN R. Vd. (2017). Sosyal Bilimlerde Araştırma Yöntemleri SPSS Uygulamalı, 9. Baskı. Sakarya Yayıncılık. Sakarya.

ÇINAR, K. ve KÖSE, T. (2019). Kamu Hizmetleri ve Vatandaş Memnuniyetinin Çok Düzeyli Analizi: Türkiye Örneği, Ekonomik Yaklaşım, 30(111):25-53.

ÇİÇEK, R. ve DOĞAN, İ.C. (2009). Müşteri Memnuniyetinin Arttırılmasında Hizmet Kalitesinin Ölçülmesine Yönelik Bir Araştırma: Niğde İli Örneği, Afyon Kocatepe Üniversitesi, İIBF Dergisi. 11(1): 199-217.

FIRAT, A.S. (2006). Belediyelerin Engellilere Dönük Sosyal Hizmet Projeleri. Toplum ve Sosyal Hizmet. 19(1):89-100.

GÖKÜŞ, M. (2010). Küreselleşme Sürecinin Kamu Hizmetine Yansıması. Selçuk Üniversitesi İIBF Sosyal ve Ekonomik Araştırmalar Dergisi. 14(20): 193-218.

GÜL S.S. vd. (2017). Türkiye'de Sosyal Belediyecilik Bağlamında Engellilere Yönelik Hizmetler: Burdur Belediyesi Örneği. Belediyelerin Geleceği ve Yeni Yaklaşımlar Bildiriler Kitabı. Cilt:1. Marmara Belediyeler Birliği Yayını. ISBN: 978-605-67424-7-7.

GÜRSAKAL, N. ve ÇELIK, S. (2020). Makine Öğrenmesi \& Derin Öğrenme İçin R Uygulamalı Doğrusal Cebir, Dora Yayıncılık, Bursa.

HACIBEBEKOĞLU, A. vd. (2015). Nazilli'de Engellilerin Memnuniyet Analizi. GEKA Projesi. Referans Numarasi: TR32/14/DFD/0028

ILO, https://www.ilo.org/ankara/conventions-ratified-by-turkey/WCMS_377302/lang-tr/index.htm (Erişim Tarihi:13.08.2020).

İNCE O. vd. (2016). Belediye Hizmetleri ve Engelli Vatandaşların Beklentileri Üzerine Amprik Bir Araştırma, Nevşehir Hacı Bektaş Veli Üniversitesi, Sosyal Bilimler Enstitüsü Dergisi, 6(2): 86-109.

KOCA, C. (2010). Engelsiz Şehir Planlaması Bilgilendirme Raporu. Dünya Engelliler Vakfı. İstanbul. 
MEB (2015). Mebk12.meb.gov.tr/meb_iys (Erişim Tarihi:10.07.2020).

SÖZER, K. vd. (2018).TR 90 Bölgesi Engelli Profili ve İhtiyaç Analizi Raporu. Doğu Karadeniz Kalkınma Ajansı Projesi.

ŞAT, N. ve GÖVER, T. (2017). Engelliler için Belediyelerin Erişebilirlik Sorunları. Hitit Üniversitesi. Sosyal Bilimler Enstitüsü Dergisi. 10(1):521-541.

ŞEKER, M. (2009). Mutluluk Ekonomisi. Sosyoloji Konferansları. Sayı:39: 115-134.

ŞEMŞiT, S. vd. (2016). Avrupa Birliği Polikaları Perspektifinden Türkiye'de Belediyelerin Sunduğu Engelli Hizmetleri. Sosyal Bilimler Dergisi. Özel Sayı. 205-223.

TÜIKK Yaşam Memnuniyeti Anketi. (tüik.gov.tr)(http://tuikweb.tuik.gov.tr/MicroVeri/YMA_2016/index.html)(Erişim: 10.07.2020).

UÇKAN, Ö. (2003). E-Devlet, E-Demokrasi ve E-Yönetişim Modeli: Bir İlkesel Öncelik Olarak Bilgiye Erişim Özgürlüğü. Ayllk Strateji ve Analiz E-Dergisi. Sayı:5:1-19.

YENIPAZARLI, A., ÇONDUR, F., CÖMERTLER, N. (2019). Engelli Bireylerin Kamu Hizmetlerinden Memnuniyeti: Nazilli İlçesi Örneği, TAEM, Uluslararası Sosyal Politikalar Kongresi, 133-150. (Tam Metin Bildiri- Sözlü Sunum), Ankara.

YURDAKUL, B.N. vd. (2011). Belediyelerde Halkla İlişkiler Yönetimi: İzmir İli Belediyelerine Yönelik Bir Araştırma. Akademik Yaklaşımlar Dergisi. 3(2):198-229.

5378 Sayılı Özürlüler (Engelliler) Kanunu. (https://www.mevzuat.gov.tr/MevzuatMetin/1.5.5378.pdf). .(Erişim: 20.07.2020).

https://www.tbmm.gov.tr/komisyon/insanhaklari/pdf01/203-208.pdf 